\title{
Assessment of whole-body occupational radiation expo- sure in industrial radiography practices in Bangladesh during 2010-2014
}

\author{
M. S. Rahman ${ }^{\text {a }}$ A. Begum ${ }^{\text {; }}$ A. Hoque ${ }^{\text {a. }}$ R. K. Khan ${ }^{\text {a }}$ M. M. M. Siraz \\ ${ }^{a}$ Health Physics Division, Atomic Energy Centre, 4 Kazi Nazrul Islam Avenue, Shahbag, Dhaka-1000, Bangladesh \\ ${ }^{b}$ Physical Science Division, Bangladesh Atomic Energy Commission, E-12/A, Agargaon, Sher-e-Bangla Nagar, \\ Dhaka-1207, Bangladesh
}

e-mail:msrahman74@hotmail.com

\begin{abstract}
Presently, ten industrial radiography facilities are operating in Bangladesh using X-ray or gamma-ray sources. During the last 5-year, 14 industrial radiography facilities were received individual monitoring service using thermoluminescent dosimeters (TLDs) from the Health Physics Division (HPD), Atomic Energy Centre, Dhaka under Bangladesh Atomic Energy Commission. HPD is the only individual monitoring service provider in Bangladesh due to external sources of ionizing radiation. The number of monitored industrial radiography facilities ranged from 7 to 14 while the number of worker ranged from 72 to 133 during the study period. The annual average effective doses received from external radiation in industrial radiography workers and the distributions of the annual effective doses by dose intervals are presented. The distribution of the occupational doses shows that the majority (about $75 \%$ ) of workers received doses below $1 \mathrm{mSv}$ for the last 5 -years. Even though, very few workers (about 1\%) received doses higher than average annual dose limit $(20 \mathrm{mSv})$, but no workers received doses higher than $100 \mathrm{mSv}$ in 5 consecutive years. The average annual effective dose of industrial radiography workers in Bangladesh is higher than the corresponding values in Tanzania, Greece, Poland, Australia, UK and lower than in Bosnia and Herzegovina, USA and Canada. However, the average annual effective dose is comparable to the corresponding values in China, Brazil, Germany and India. The status and trends in occupational doses show that radiation protection situation at the majority of the workplace were satisfactory. In spite of that, additional measures are required due to big differences observed in the maximum individual doses over the last 5-year.
\end{abstract}

Keywords: industrial radiography, thermoluminescent dosimeter, effective dose. 


\section{INTRODUCTION}

Industrial radiography work is often carried out under difficult working conditions, such as in confined spaces, in extreme cold or heat, or during the night. Working under such adverse conditions might results in operational situations in which occupational radiation protection may be compromised. Gamma radiography equipment utilizes a high activity sealed source housed in a shielded exposure device. Improper management of high-activity sources can have severe deterministic effects on individuals [1-7]. Based on the potential hazards of radioactive sources, a system of categorization has been developed by the International Atomic Energy Agency (IAEA) $[8,9]$. Industrial radiography is one of the most common non-destructive testing (NDT) methods worldwide and must be managed very safely and securely. Industrial radiographers are considered one of the most critical group of radiation workers. The annual average effective dose received by industrial radiographers is higher than that of other radiation workers [10]. With regard to this fact and according to the Bangladesh Atomic Energy Regulatory (BAER) Act-2012 [11], any activity in this field shall be performed only after obtaining a proper licence. All applicants must submit the necessary documents to the Bangladesh Atomic Energy Regulatory Authority (BAERA) and ensure that they have the competence to carry out all activities with the proper administrative and technical measures.

Any individual radiation monitoring program has at least two main aims. The first aim is to provide information on the adequacy of protection measures which is a key input for operational decisions related to the optimization principle $[12,13]$. Secondly, the individual monitoring programs aim is to demonstrate compliance with the relevant dose limits as required by the national regulations [14] and recommendations of International Organizations [12, 13, 15]. In this context, the annual effective dose to the occupationally exposed workers should not exceed $20 \mathrm{mSv}$ averaged over five consecutive years (100 $\mathrm{mSv}$ in 5 -years), with a provision that the individual dose does not exceed $50 \mathrm{mSv}$ in any single year. Regular assessment of occupational radiation exposures and the analysis of related trends are vital to examine changes that have taken place over time due to regulatory operations or technological improvements. The objectives of this 
paper were to present the occupational radiation exposure of workers in industrial radiography practices in Bangladesh and to evaluate the related trends over a period of 2010-2014.

\section{MATERIALS AND METHODS}

\subsection{Description of TLDs and readout process}

The thermoluminescent dosimeters (TLD) consists of LiF:Mg,Ti (TLD-100); phosphor has the effective atomic number of 8.2, approximately equivalent to that of the soft tissue of a human body. TLD chips $3 \mathrm{~mm}$ (1/8 inch) square encapsulated between two sheets of Teflon 0.003 inches $\left(10 \mathrm{mg} / \mathrm{cm}^{2}\right)$ thick and mounted on an aluminum substrate. In this study, two-chip TLD cards kept in a holder are issued for quarterly (3 months) basis to the radiation workers working in industrial radiography facility (IRF). The worker wears the TLD on torso at the working time. After using the cards of the stipulated time, IRF send back those used TLDs to the Health Physics Division (HPD), Atomic Energy Centre, Dhaka (AECD) under Bangladesh Atomic Energy Commission (BAEC). The Harshaw TLD reader (model 4500) is used for measurement of TLD dose of a wide varity of thermolumincence (TL) materials in many forms and sizes [16]. It has two photomultiplier tube (PMT) in a sliding housing for manual reading of TLD cards and TL chips for whole body, extremity and environmental dose monitoring purposes. Dual PMTs and associated electronics enable it to read cards in two positions simultaneously. PMT consists of photocathode that has the ability to convert the incident light into amplified current to give measured output which is proportional to the number of generated photons and as a result proportional to the absorbed dose. The Harshaw automatic TLD reader (model 6600 plus) has two heating methods such as hot nitrogen gas and dry air [17]. The doses of the received TLDs are measured in the TLD Reader by using hot nitrogen gas flow. The gas heating system uses a stream of hot nitrogen at precisely controlled, linearly ramped temperatures to a maximum of $300^{\circ} \mathrm{C}$. The hot gas heating under closed loop feedback control and the superior electronic design produces consistent and repeatable glow curves. The annealed TLD again issue along with the dose report to the relevant worker for use of next quarter cycle. 


\subsection{Equipments and dose evaluation procedures}

The operational dose quantity used for the estimation of doses from external radiation is the personal dose equivalent $\mathrm{H}_{\mathrm{p}}(10)$. Monitoring of radiation workers by the HPD, AECD under BAEC using TLDs begin immediately after a facility is licensed to operate. HPD, AECD is the only institute that provides dosimetry service for facilities that employ the use of ionizing radiation in Bangladesh. LiF:Mg, Ti (TLD-100) dosimeters have been used throughout the period 20102014. In the same period, two thermoluminescent dosimetry systems have been employed to readout the TLDs. They are Harshaw Manual TLD Reader, Model 4500 [16] (from 2000 and still running) and Automatic TLD Reader, Model 6600 Plus [17] (from June 2014) with manual system of data transfer. Harshaw 6600 plus Automatic TLD Reader which is one of the most technically advanced dosimetry systems for whole body, extremity, neutron and environmental monitoring, is being used by the HPD, AECD. The system offers 'one dosimetry solution' by its ability to monitor whole body (beta, photon and neutron), extremity and environmental exposure with a single dosimeter. It can take up to 200 dosimeters per cycle and also saves significant time by virtue of its automatic calibration capabilities. It has a flat panel display and touch-screen operation service and it exceeds International Electrotechnical Commission (IEC), International Organization for Standardization (ISO) and American National Standards Institute Performance requirements. The Harshaw TLD Readers are connected to an external personal computer (PC) and are operated through installed menu-driven WinREMS software.

The Secondary Standard Dosimetry Laboratory (SSDL) has been available at BAEC since 1991, which is traceable to the Primary Standard Dosimetry Laboratory (PSDL) of National Physical Laboratory (NPL), UK. Prior to use, each TLD is exposed with $2 \mathrm{mSv}$ dose from SSDL of BAEC with respect to $\mathrm{H}_{\mathrm{p}}(10)$, using a ${ }^{137} \mathrm{Cs}$ beam incident on a slab phantom of PMMA for measurement of elemental correction coefficient (ECC). SSDL of BAEC has X-ray Unit (30 kV$225 \mathrm{kV}$ ) for calibration of TLDs. The performance of BAEC SSDL is maintained according to the requirements of the International Atomic Energy Agency (IAEA)/World Health Organization (WHO) network of SSDLs. Therefore, the evaluated doses are traceable to the international measurement system. Furthermore, the personal monitoring laboratory regularly participates in inter-laboratory dose comparison programmes as organized by IAEA. In the latest comparison, adequate performance was achieved according to the standards trumpet curve criteria $[18,19]$. 
TLDs output read by Harshaw TLD reader is the charges produced by electrons due to the annealing process. To convert the output readings of TLDs from charge (nC) to absorbed dose (Gy); the following equations are used:

absorbed dose $=\frac{\text { equivalent dose }}{\text { quality factor }}$

The time between irradiation and readout should be the same to keep same fading from one calibration to another for all TLDs. The calibration factor ( $\left.f_{\text {calibration }}\right)$ is defined as follows:

$f_{\text {calibration }}=\frac{D_{\text {ionization chamber }(m G y)}}{T L D_{\text {reading }(n C)}}$

Absorbed dose due to irradiation is obtained after background subtraction by the following equation:

$D_{T L D}=D_{a v}-B G$

Then absorbed dose is obtained for each TLD by the following equation:

$D_{T L D}(m G y)=f_{\text {cal }}\left(\frac{m G y}{n C}\right) \times T L D_{\text {reading }}(n C)$

Dose reporting is performed on a quarterly basis. For all individual doses, the minimum detection level (MDL) is $0.05 \mathrm{mSv}$ for 3 months for two TLD systems after background subtraction. This value (MDL) is taken as dose recording level. The workers who received doses less than MDL are regarded as non-exposed. All doses that exceed the level of $5 \mathrm{mSv}$ in a monitoring period (3 months) are always investigated. The dose record is accordingly amended after receiving a written explanation with reasons of high dose received by the workers from the Radiation Protection Officer/Head of the Institution. The database, therefore, includes only actual doses received by the radiation workers. Table 1 shows the number of monitored workers for the years 2010-2014.

\subsection{Monitored and exposed workers}

The dosimetry service at HPD uses a personal dosimeter system with a MDL of $0.05 \mathrm{mSv}$ for a three month monitoring period after subtracting background radiation. Exposed workers are workers who may be exposed to doses exceeding $0.05 \mathrm{mSv}$. The workers who have effective 
doses less than MDL are considered as non-exposed. Therefore, the doses less than MDL are recorded as zero. All values of $\mathrm{H}_{\mathrm{p}}(10)$ are recorded and reported as the effective dose.

Table 1: Number of monitored workers in industrial radiography practices for the years 20102014 (enclosed in the brackets in the column are the number of institutions).

\begin{tabular}{cccccc}
\hline $\begin{array}{c}\text { Type of practice } \\
\text { /Year }\end{array}$ & $\mathbf{2 0 1 0}$ & $\mathbf{2 0 1 1}$ & $\mathbf{2 0 1 2}$ & $\mathbf{2 0 1 3}$ & $\mathbf{2 0 1 4}$ \\
\hline $\begin{array}{c}\text { Industrial radiog- } \\
\text { raphy }\end{array}$ & $72(7)$ & $84(9)$ & $129(11)$ & $133(11)$ & $130(12)$ \\
\hline
\end{tabular}

\subsection{Data Analysis}

In this study, four quantities recommended by UNSCEAR [20] were used to analyze individual doses for the years 2010-2014. They include the annual collective effective dose, the average annual effective dose, the individual dose distribution ratio and the annual collective effective dose distribution ratio. In addition, the minimum and the maximum values of the annual individual effective doses were analyzed to complement the average annual effective doses.

\subsubsection{Annual collective effective dose (S)}

The annual collective effective dose (S) was obtained according to the following equation given by UNSCEAR [20]:

$$
S=\sum_{i=1}^{N} E_{i}
$$

Where $E_{i}$ is the annual effective dose received by the $i^{\text {th }}$ worker and $\mathrm{N}$ is the total number of workers monitored. The parameter S, gives an estimate of the impact of particular practice on the population in given time frame.

\subsubsection{Average annual effective dose}

The average annual effective dose, $\bar{E}$ was obtained from the ratio $\mathrm{S} / \mathrm{N}$, where the meaning of symbols are the same as in equation (5). 


\subsubsection{The individual dose distribution ratio}

The individual dose distribution ratio, $\mathrm{NR}_{\mathrm{E}}$ was obtained according to the following equation [20]:

$$
N R_{E}=\frac{N(>E)}{N}
$$

Where $\mathrm{N}(>\mathrm{E})$ is the number of workers receiving annual dose exceeding $\mathrm{E} \mathrm{mSv}$. In this study, $\mathrm{NR}_{\mathrm{E}}$ was analysed for values of $\mathrm{E}$ of $1,5,10$ and $15 \mathrm{mSv}$. The parameter $\mathrm{NR}_{\mathrm{E}}$ provides an indication of the fraction of workers exposed to higher levels of individual doses.

\subsubsection{The annual collective dose distribution ratio}

The annual collective dose distribution ratio, $\mathrm{SR}_{\mathrm{E}}$ was obtained according to the following equation [20]:

$$
S R_{E}=\frac{S(>E)}{S}
$$

Where $\mathrm{S}(>\mathrm{E})$ is the annual collective dose delivered at an annual dose exceeding $\mathrm{E} \mathrm{mSv}$. In this study, $\mathrm{SR}_{\mathrm{E}}$ was analysed for values of $\mathrm{E}$ of 1, 5, 10 and $15 \mathrm{mSv}$. The parameter SRE, provides an indication of the fraction of the collective dose received by workers exposed to higher levels of individual doses.

\section{RESULTS AND DISCUSSION}

\subsection{Annual average effective dose and collective effective dose}

The annual average effective dose and annual collective effective dose did not follow a particular trend between the 5-year periods. The annual average doses of the monitored workers were ranged 1.12-1.74 mSv during the period 2010-2014 as shown in Figure 1. The average annual effective dose of the monitored workers for the last 5 -year period was $1.40 \mathrm{mSv}$ which is compa- 
rable to the worldwide average annual effective dose of $1.50 \mathrm{mSv}$ during 1995-1999, 2000-2002 periods [21]. The lowest annual average effective dose was $1.12 \mathrm{mSv}$ in 2011. The observation may be due to decrease in workload or adherence to proper radiation protection protocols in 2011. The sudden rise in annual average effective dose in 2012 and 2013 could be due to improper radiation protection measures resulting in unintended over exposure of certain TLDs [22]. The decrease in average annual effective dose after 2013 is probably due to the formulation of independent regulatory Authority (BAERA) under the BAER Act-2012 [11] and proper regulatory control of the industrial radiography facilities. The annual maximum individual effective doses were 23.65, 21.71, 54.14, 55.37 and $12.49 \mathrm{mSv}$ in 2010, 2011, 2012, 2013 and 2014 respectively as shown in Figure 2. It is the policy of HPD, BAEC dosimetry service to write to employers if any recorded dose exceeds $5 \mathrm{mSv}$ for a monitoring period of 3 months. The employer is informed immediately of the dose and is requested to investigate the incident and to report the findings of such investigation to the HPD, BAEC. It is found that most of these exposures were due to prolonged working with radioactive sources at on-sites or mistakes by radiation workers. X-rays and gamma-ray sources such as ${ }^{192}$ Ir are widely used for industrial radiography in Bangladesh. Most of these workers might not have proper training on radiation protection and their high exposure dose is thought to be the result of improper handling of the radioactive sources during their daily work. As can be seen from Figure 3, the majority of workers (75\%) received doses less than $1 \mathrm{mSv}$ during the entire study period. This means that the distributions are left skewed towards low doses in accordance with the distribution pattern described by UNSCEAR [23], the implication of which is that most occupationally exposed workers received very low doses with only a small number receiving high doses. During the period 2010-2014, two workers received doses higher than $50 \mathrm{mSv}(54.14 \mathrm{mSv}$ in 2012 and $55.37 \mathrm{mSv}$ in 2013), while 4 workers received doses higher than annual average permissible dose limit (20 mSv) $(23.65 \mathrm{mSv}$ in 2010, $21.71 \mathrm{mSv}$ in 2011, $36.44 \mathrm{mSv}$ in 2012 and $36.58 \mathrm{mSv}$ in 2013). Currivan and Koczynski $[24,25]$ investigated that industrial radiography workers received higher doses than their counterparts in the medical group is a common phenomenon. Based on this observation, as in most countries, industrial workers are the ones at risk and therefore rigorous surveillance has to be maintained in order to reduce the doses to this group of workers. The surveillance programme 
should include an analysis of worker dose records to determine whether the same set of workers always receives the higher doses.

Figure 1: Trends of annual collective dose and average dose of the workers in industrial radiography practices.

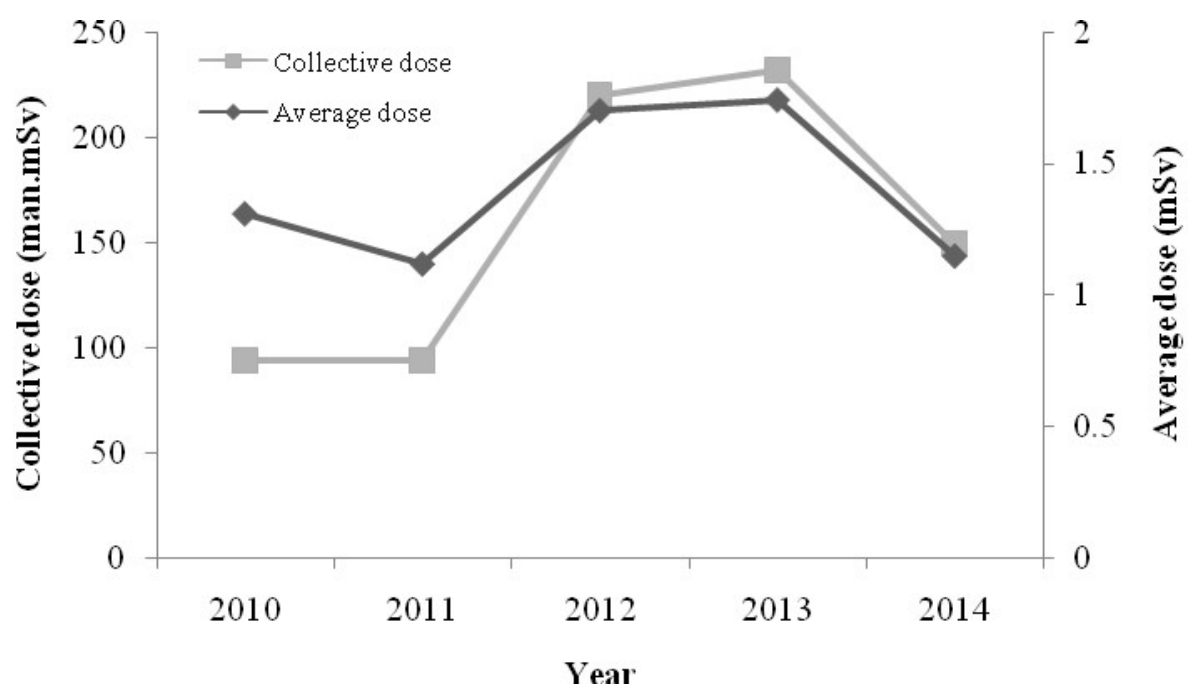

Figure 2: Maximum individual annual effective dose from 2010 to 2014.

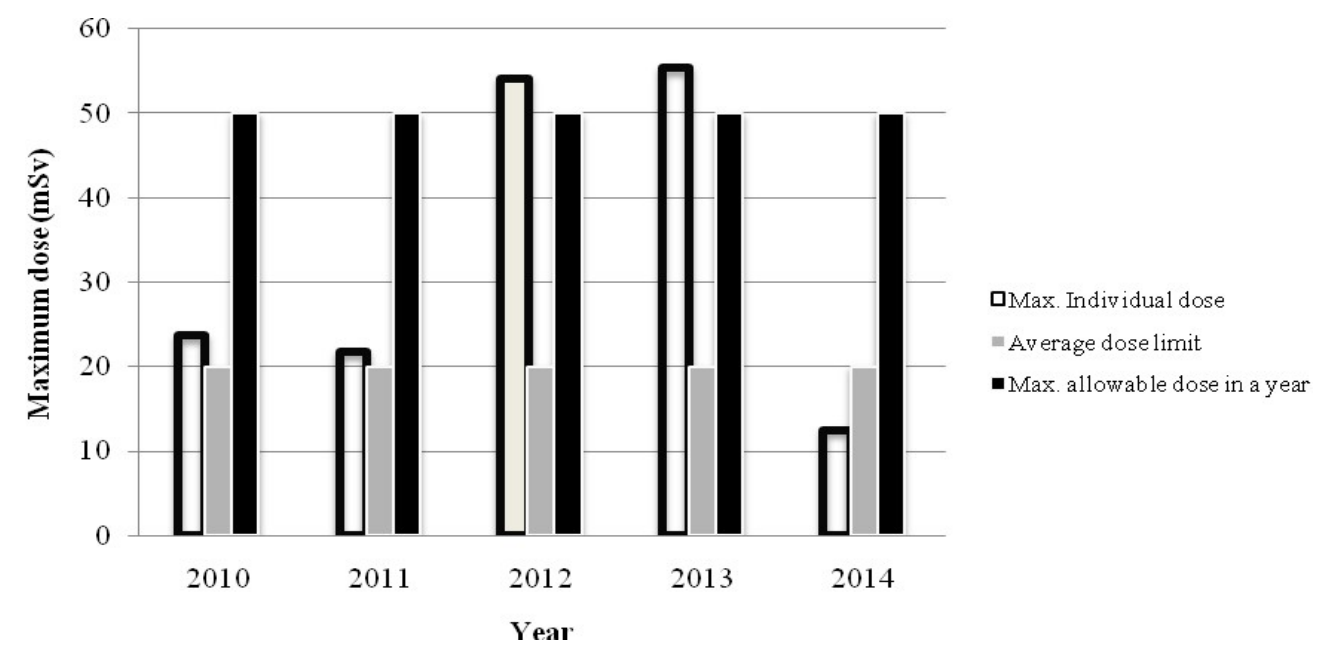


Figure 3: Number of workers average annual effective doses interval in industrial radiography practices during the period 2010-2014.

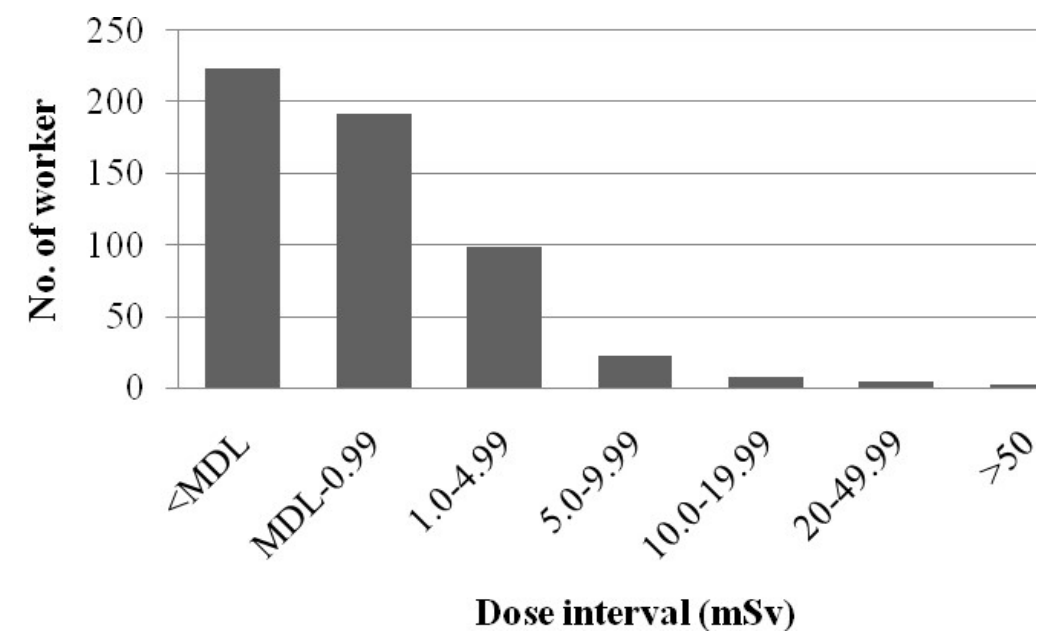

The comparisons with other countries data (Table-4) in literature show varying results. For example, in Tanzania, average annual effective dose for the years 1996-2010 was $0.59 \mathrm{mSv}$. In Greece, the average annual effective dose for the years 1996-2003 was 0.56 mSv, while in China, average annual effective dose for the years 1996-2000 was $1.18 \mathrm{mSv}$. In Bosnia and Herzegovina, average annual effective dose for the years 2004-2008 was $3.4 \mathrm{mSv}$, while in USA, average annual effective dose for the years 2000-2002 was $5.36 \mathrm{mSv}$. Therefore the average annual occupational exposure in Bangladesh is largely within the ranges of exposure situations that are found in other countries.

Considering the global condition, the worldwide average effective dose for monitored workers is $1.50 \mathrm{mSv}$ during 1995-1999 and 2000-2002 [21]. The results from this work show that for the years 2010-2014, the average annual effective dose for monitored workers was $1.40 \mathrm{mSv}$. Therefore the average annual effective dose for industrial radiography workers in Bangladesh is higher than the corresponding values in Tanzania, Greece, Poland, Australia, UK and lower than in Bosnia and Herzegovina, USA and Canada. The average annual effective dose for industrial radiography workers in Bangladesh is comparable to the corresponding values in China, Brazil, Germany and India [30, 20]. It is to be noted that the doses for these countries correspond to different time periods. The variations can be accounted for by the differences in the workloads of practices, the state of the technology or the understanding level on radiation protection. 


\subsection{Individual and collective dose distribution ratio}

The individual dose distribution ratios for the period 2010-2014 were presented in Table 2. It is seen that very few individuals were exposed to doses exceeding 10 and $15 \mathrm{mSv}$. Furthermore, less than $3 \%$ of the monitored workers received doses above $10 \mathrm{mSv}$. Table 3 presents the results of the collective dose distribution ratio for the period 2010-2014.

Table 2: The individual dose distribution ratio for the period 2010-2014.

\begin{tabular}{|c|c|c|c|c|c|}
\hline \multirow{2}{*}{$\begin{array}{l}\text { Annual } \\
\text { individual } \\
\text { dose ex- } \\
\text { ceeding } \\
(\mathrm{mSv})\end{array}$} & \multicolumn{5}{|c|}{ Individual dose distribution ratio } \\
\hline & 2010 & 2011 & 2012 & 2013 & 2014 \\
\hline 1 & 0.208 & 0.167 & 0.232 & 0.256 & 0.307 \\
\hline 5 & 0.069 & 0.071 & 0.054 & 0.060 & 0.069 \\
\hline 10 & 0.027 & 0.024 & 0.023 & 0.030 & 0.015 \\
\hline 15 & 0.014 & 0.012 & 0.023 & 0.022 & 0.00 \\
\hline
\end{tabular}

Table 3: Collective dose distribution ratio for the period 2010-2014.

\begin{tabular}{llllll}
\hline $\begin{array}{l}\text { Annual } \\
\text { individual } \\
\text { dose ex- } \\
\text { ceeding } \\
\text { (mSv) }\end{array}$ & $\mathbf{2 0 1 0}$ & $\mathbf{2 0 1 1}$ & $\mathbf{2 0 1 2}$ & $\mathbf{2 0 1 3}$ & $\mathbf{2 0 1 4}$ \\
\cline { 2 - 6 } & & & & & \\
$\mathbf{1}$ & 0.629 & 0.701 & 0.688 & 0.718 & 0.667 \\
$\mathbf{5}$ & 0.522 & 0.594 & 0.583 & 0.605 & 0.425 \\
$\mathbf{1 0}$ & 0.363 & 0.381 & 0.492 & 0.510 & 0.151 \\
$\mathbf{1 5}$ & 0.251 & 0.231 & 0.492 & 0.464 & 0.00 \\
\hline
\end{tabular}


Table 4: Comparison of annual average effective dose of monitored and exposed workers with other countries.

\begin{tabular}{|c|c|c|c|c|}
\hline \multirow[t]{2}{*}{ Country } & \multicolumn{4}{|c|}{ Annual average effective dose (mSv) } \\
\hline & Period & $\begin{array}{c}\text { Monitored } \\
\text { Worker }\end{array}$ & $\begin{array}{l}\text { Exposed } \\
\text { Worker } \\
\end{array}$ & Reference \\
\hline Tanzania & $1996-2010$ & 0.59 & - & MUHOGORA, W. E. et al [26] \\
\hline Greece & $1996-2003$ & 0.56 & - & Economides, S. et al [27] \\
\hline \multirow[t]{2}{*}{ Turkey } & 1995-1999 & 0.30 & - & Gunduz, H. et al [28] \\
\hline & 2003 & 1.35 & - & Zeyrek, C.T. et al [29] \\
\hline \multirow[t]{3}{*}{ China } & $1986-1990$ & 1.92 & - & TIAN, Y. et al [30] \\
\hline & 1991-1995 & 1.43 & - & \\
\hline & $1996-2000$ & 1.18 & - & \\
\hline Bosnia & $1999-2003$ & 3.0 & 5.8 & BASIC, B. et al [31] \\
\hline $\begin{array}{c}\text { And Herzego- } \\
\text { vina }\end{array}$ & 2004-2008 & 3.4 & 4.1 & \\
\hline \multirow[t]{2}{*}{ Poland } & 1999 & 0.80 & - & KOCZYNSKI, A. et al [25] \\
\hline & 2011 & 0.48 & - & WASEK, M. et al [32] \\
\hline \multirow[t]{2}{*}{ USA } & 1995-1999 & 4.13 & 5.51 & UNSCEAR 2008 [21] \\
\hline & $2000-2002$ & 5.36 & 6.40 & \\
\hline Argentina & 1990-1994 & 0.83 & 2.90 & UNSCEAR 2000 [20] \\
\hline Australia & 1990-1994 & 0.19 & 0.46 & UNSCEAR 2000 [20] \\
\hline Brazil & 1990-1994 & 1.40 & 3.13 & UNSCEAR 2000 [20] \\
\hline Bulgaria & 1990-1994 & 0.87 & 1.63 & UNSCEAR 2000 [20] \\
\hline Canada & 1990-1994 & 3.39 & 5.82 & UNSCEAR 2000 [20] \\
\hline Germany & 1990-1994 & 1.41 & 4.29 & UNSCEAR 2000 [20] \\
\hline India & 1990-1994 & 1.84 & 3.49 & UNSCEAR 2000 [20] \\
\hline Japan & 1990-1994 & 0.83 & 2.57 & UNSCEAR 2000 [20] \\
\hline UK & 1990-1994 & 0.76 & 1.55 & UNSCEAR 2000 [20] \\
\hline Bangladesh & 2010-2014 & 1.40 & 2.43 & This study \\
\hline \multirow{2}{*}{$\begin{array}{c}\text { Worldwide } \\
\text { average }\end{array}$} & 1995-1999 & 1.50 & - & UNSCEAR 2008 [21] \\
\hline & $2000-2002$ & 1.50 & - & \\
\hline
\end{tabular}




\section{CONCLUSION}

The average annual effective dose is comparable to the worldwide average annual effective dose as quoted in the literature. Even though majority of workers received very low doses, but a very few workers received doses above annual average dose limit. Therefore, a close monitoring and control of the activities of this group of workers must be ensured. The following may be some of the reasons for high doses in any industrial radiography institution.

(1) Employ of workers who are not qualified or trained. Such workers may not know the implication of exposing themselves to unnecessary high radiation doses.

(2) Inadequate performance of radiation generating equipments due to ageing and lack of maintenance.

(3) Insufficient number of workers in the different institutions leading to workers high workload.

From this observation, it can be concluded that courses in radiation protection particularly the safe operation of the radiation generating equipments and radioactive sources are strongly recommended to those workers who have lack of proper training. Finally, workers should pay more attention to radiation protection procedures and guidelines in every exposure to keep the doses below the annual average permissible limit rather than maximum allowable dose in a year.

\section{ACKNOWLEDGMENT}

The authors wish to express their gratitude to their colleagues for their support. The International Atomic Energy Agency (IAEA) is thanked for providing TLD readers through national Technical Cooperation Project. 


\section{REFERENCES}

1. IAEA-International Atomic Energy Agency. Lessons learned from accidents in industrial radiography, Safety Report Series No. 7 (Vienna, IAEA, 1998).

2. IAEA-International Atomic Energy Agency. The Radiological Accident in Gilan (Vienna: IAEA, 2002).

3. IAEA-International Atomic Energy Agency. The Radiological Accident in Tammiku (Vienna: IAEA, 1998).

4. IAEA-International Atomic Energy Agency. The Radiological Accident in Samut Prakarn (Vienna: IAEA, 2002).

5. IAEA-International Atomic Energy Agency. The Radiological Accident in Goiania (Vienna: IAEA, 1988).

6. IAEA-International Atomic Energy Agency. The Radiological Accident in San Salvador (Vienna: IAEA, 1990).

7. IAEA-International Atomic Energy Agency. The Radiological Accident in Yanango (Vienna: IAEA, 2000).

8. IAEA-International Atomic Energy Agency. Categorization of Radioactive Sources, IAEA Safety Standard Series No. RS-G-1.9 (Vienna: IAEA, 2005).

9. MIANJI, F. A.; KARDAN, M. R.; and RASTKHAH, N. Survey on lost and poorly controlled radioactive sources in non-medical applications in Iran. Radiat. Prot. Dosim., v. 118(4), p.375-377, 2006.

10. UNSCEAR-United Nations Scientific Committee on the Effects of Atomic Radiation. Sources and Effects of Ionizing Radiation Report to General Assembly, with Scientific Annexes (New York: United Nations, United Nations Sales Publication E.00.IX.3, 2000).

11. Bangladesh Atomic Energy Regulatory (BAER) Act-2012 (Act No. 19 of 2012), 2012.

12. The Nuclear Safety and Radiation Control (NSRC) Rules-1997 of Bangladesh (SRO No. 205-Law/97), 1997. 
13. ICRP-International Commission on Radiological Protection. The 2007 Recommendations of International Commission on Radiological Protection. ICRP Publication 103. Ann. of ICRP 37 (2- 4), Pergamon Press, Oxford and New York, 2007.

14. IAEA-International Atomic Energy Agency. Radiation Protection and Safety of Radiation Sources: International Basic Safety Standards. General Safety Requirements Part-3, (Vienna, IAEA, 2014).

15. ICRP-International Commission on Radiological Protection. ICRP Statement on Tissue Reactions / Early and Late Effects of Radiation in Normal Tissues and Organs Threshold Doses for Tissue Reactions in a Radiation Protection Context. ICRP Publication 118. Ann. ICRP 41(1/2), Pergamon Press, Oxford and New York, 2012.

16. Harshaw Model 4500, Manual TLD Workstation Operator's Manual (Cochran Road, Solon, Ohio) (Pub. No. 4500-0-O-0598-002, 6801), 2007.

17. Harshaw TLD Model 6600 Plus Automatic TLD reader user manual. Thermo Fisher Scientific Inc., 2007 Available at: http://www.kortec.cz/files/thermo/TLDModel6600.pdf.

18. IAEA-International Atomic Energy Agency. Assessment of occupational exposures due to external sources of radiation. Safety Guides Series No. RS-G-1.3, (Vienna, IAEA, 1999).

19. ICRP-International Commission on Radiological Protection. General Principles for the radiation protection of workers, First edn. Annals of the ICRP 27 (1), Pergamon Press, Oxford and New York, 1997.

20. UNSCEAR-United Nations Scientific Committee on the Effects of Atomic Radiation. Report to the General Assembly with Scientific Annexes, volume I, Annex E. (United Nations, New York, USA, 2000).

21. UNSCEAR-United Nations Scientific Committee on the Effects of Atomic Radiation. Sources and Effects of Ionizing Radiation. Report to General Assembly with Scientific Annexes, volume I, Annex B (New York: United Nations, United Nations Publication Sales No.E.10.XI.3, 2008). 
22. HART, D. and WALL, B. F. Radiation exposure to the UK population from medical and dental x-ray examinations. National Radiological Protection Board, NRPB-W4, 2004.

23. UNSCEAR-United Nations Scientific Committee on the Effects of Atomic Radiation. Ionizing radiation: sources and biological effects. United Nations Scientific Committee on the Effects of Atomic Radiation (New York: United Nations, E82. IX.8, 1982).

24. CURRIVAN, L.; DONELLY, H.; DAWSON, D.; SPAIN, D. and COLGAN, P. A. Analysis of whole-body doses received by occupationally exposed workers in Ireland (1996-1999). Radiat. Prot. Dosim., v. 96(1-3), p.53-56, 2001.

25. KOCZYNSKI, A.; CHEC, A.; LACH, D. and DABEK, M. Occupational exposure to external ionizing radiation in Poland, 1999. Radiat. Prot. Dosim., v. 96 (1-3), p.61-62, 2001.

26. MUHOGORA, W. E.; BYORUSHEENGO, E.; LEMA, U.S.; MBOYA, G.; NGATUNGA, J.B.;SAWE, S.; KATSIDZITA, N.M.; MIKIDADI, S.;CHUMA, F.;MARCO, A.; and HAMED, M.I. Occupational radiation exposure in Tanzania (1996-2010): status and trends. Radiat. Prot. Dosim., v. 153(4), p.403-410, 2013.

27. ECONOMIDES, S.; TRITAKIS, P; PAPADOMARKAKI, E; CARINOU, E.; HOURDAKIS, C.; KAMENOPOULOU, V. and DIMITRIOU, P. Occupational exposure in Greek industrial radiography laboratories (1996-2003). Radiat. Prot. Dosim., v. 118(3), p.260-264, 2006.

28. GUNDUZ, H.; ZEYREK, C. T.; AKSU, L. and ISAK, S. Occupational exposure to ionizing radiation in the region of Anatolia, Turkey for the period 1995-1999. Radiat. Prot. Dosim., v.108 (4), p.293-301, 2004.

29. ZEYREK, C. T. and GUNDUZ, H. Occupational exposure to ionizing radiation with thermoluminescent dosimetry system in Turkey, in 2003. Radiat. Prot. Dosim., v.113 (4), p.374-380, 2005.

30. TIAN, Y.; ZHANG, L. and JU, Y. Dose level of occupational exposure in China. Radiat. Prot. Dosim., v.128 (4), p.491-495, 2008. 
31. BASIC, B.; BEGANOVIC, A.; SAMEK, D.; SKOPLJAK-BEGANOVIC, A. and GAZDIC-SANTIC, M. Ten years of monitoring the occupational radiation exposure in Bosnia and Herzegovina. Radiat. Prot. Dosim., v.139 (1-3), p.400-402, 2010.

32. WASEK, M.; SZEWCZAK, K. and WROCZYNSKI, P. Exposure to ionizing radiation of workers in Poland. Acta Poloniae Pharmaceutica - Drug Research, v.69, p.13871389, 2012. 